\title{
Loyalty in the Supermarket
}

\author{
Valter A. Vieira* \\ E-mail address: valter23@yahoo.com \\ PPGA/Universidade de Brasília - UnB \\ Brasília, DF, Brazil

\section{Cláudio Damacena} \\ E-mail address: damacena@uol.com.br \\ Universidade do Vale do Rio dos Sinos - UNISINOS \\ São Leopoldo, RS, Brazil
}

\begin{abstract}
Loyalty has been a hot topic in marketing management, not only for academics, but also for managers. In that sense, the main goal of this paper is to identify the variables that discriminate loyalty groups. Therefore, seven hypotheses have been proposed which might have an impact on loyalty groups. Based on discriminant analysis, the paper analyzes and discusses the data, and presents a conclusion that the more important variables on loyalty in the supermarket are affective commitment, satisfaction with its environment and value provided by supermarket experiences. Moreover, the results also indicated that the theoretical model achieved a variance in the loyalty construct of canonical R-squared $=0.78$. It could be considered a good value to the final model. Final considerations and study limitations conclude the paper.
\end{abstract}

Key words: loyalty; affective commitment; discriminant analysis.

Copyright (C) 2007 Brazilian Administration Review. All rights reserved, including rights for translation. Parts of this work may be quoted without prior knowledge on the condition that the source is identified.

*Corresponding author: Valter A. Vieira

Rua Viuvinha, 69, Conjunto Centauro, 86709-349, Arapongas/PR, Brazil. 


\section{INTRODUCTION}

Loyalty has been a hot topic in marketing management, not only for academics, but also for managers. From the time that Oliver $(1997,1999)$ stated that researchers needed to stop researching satisfaction and should start studying the loyalty construct, academia began to notice a remarkable change in the topic of papers published. Thus, since that time, we have realized that many studies are focusing on loyalty in the literature. In this context, understanding the antecedents of loyalty seems to be an important strategic tool for the retail market. Being more specific, knowing the variables that could explain the main differences between loyalty groups (for example, loyal versus non-loyal) could be vital to the competitiveness of the supermarket segment (Sirohi, McLaughlin, \& Wittink, 1998).

In practice, marketing strategists were able to analyze the variables that help most in discriminating the loyal group from the non-loyal group, creating marketing programs that sought to turn non-loyal groups into loyal consumers. Based on this perspective, this study analyzes the literature and presents seven hypotheses that could help tell the difference between non-loyal groups and loyal groups. The main goal of this paper is to identify the variables that distinguish loyalty groups.

The study initially proposes the seven hypotheses. Next, it discusses the theoretical concepts, the scales and the methods used in the research field. Based on discriminant analysis, it analyzes and discusses the data, and presents a conclusion that the more important variables on loyalty in the supermarket are affective commitment, satisfaction with its environment and the value provided by supermarket experiences.

\section{THEORY AND HYPOTHESIS DEVELOPMENT}

Beginning at the company level, image has been defined as perceptions of an organization reflected in the associations consumers bear in their memories (Keller, 1993). The history of corporate image definition reveals convergence on a Gestalt meaning, but one that overlooks corporate attributes and focuses exclusively on perceived images (Ster, Zinkhan, \& Jaju, 2001) begins to appear - the transactional process. According to this meaning, the process is developed between the brand stimulus and consumer perception. Thus, it is hoped that consumers start their purchase process by evaluating the image of something or by remembering the old images stored in their memories (mainly the positive ones). The transactional process suggests that individuals prefer stores whose image is positive.

Consumers develop store images based on the quality of service they have experienced, advertising and opinions of friends and relatives (Assael, 1998). As store image is the total perception formulated by consumers' experience, knowledge, and belief, it has a strong effect on consumers' buying behavior and helps consumers evaluate the differences between shops and choose one among them (E. Lee \& D. Lee, 2005).

In this context, key to perceptions of corporate image is the organization-related associations customers hold in their memories (Johnson, Gustafsson, Andreassen, Lervik, \& Cha, 2001). Since consumers could evoke past experiences (Keller, 1993) in a future purchase situation, a previously constructed image could be an explanatory variable of loyalty, because image has to do with how customers perceive an organization based on experience or impressions and how these perceptions create a set of associations that contribute to a total picture of the organization (Selnes, 1993). In turn, the corporate image should affect effective behavioral intentions, such as loyalty, because consumers should prefer those stores whose image has a positive meaning in their memory. Selnes (1993) hypothesized this result for brand reputation and found consistent results. According to this author, corporate image is a construct that is similar to the self-concept construct in psychology, in which both 
refer to a set of thoughts and feelings having an object as reference (e.g. a company or person). This means that image has a positive and significant impact on loyalty. Other studies also support the fact that corporate image is a predictor of loyalty (for example, Bloemer \& Schroder, 2002; Kristensen, Martensen, \& Gronholdt, 2000; Leite, Elias, \& Sundermann, 2005; Loughlin \& Coenders, 2002). Consequently, if corporate image is a predictor of loyalty, corporate image is expected to discriminate customer loyalty groups. Based on these circumstances, the hypothesis is:

\section{$\mathrm{H}_{1}$ : Corporate image has a positive influence on the categorization of different loyalty groups.}

The next causal link has to do with complaint handling and loyalty behavior. Although no prediction is made regarding this relationship, the direction and size of this relationship provides some diagnostic information as to the efficiency of a firm's customer service and complaint handling systems (Fornell, 1992). Johnson et al. (2001) believe that complaint handling, which is now used instead of complaint behavior, should have a direct and positive effect on loyalty. The argument presented by some studies suggests that the basis for that relation comes from the justice concept (Blodgett, Hill, \& Tax, 1997; Tax, Brown, \& Chandrashekaran, 1998). The concept of fairness, as it is also called, has been widely and successfully employed to explain individuals' reactions to a variety of conflict situations, including complaint resolution processes (Santos \& Singh, 2003). The way that complaints are received and managed creates an affective response, i.e. satisfaction, which impacts on the capacity of people to shop again at the same store; see, for instance, the Equity Theory (Messick \& Cook, 1983). As a consequence of such handling by the company, it may be clear that when repurchasing the product or service, past complaint handling and perceived justice (Goodwin \& Ross, 1992) may have a direct and positive effect on the cognitive assessment of the supermarket, leading to an increase in purchase intention. Another argument that could explain the relationship between complaint handling and loyalty behavior is based on the Social Transaction Theory, in which both parties involved in an exchange are motivated to repay the benefits and treatment obtained from such exchange (Thibaut \& Kelley, 1959). Therefore, the next hypothesis is:

\section{$\mathrm{H}_{2}$ : Complaint Handling has a positive influence on the categorization of different loyalty groups.}

According to Johnson et al. (2001), because quality is part of value, the relationship between perceived quality and perceived value is confused. As a result, the authors recommended replacing the perceived value construct with a perceived price construct. In fact, in those cases "where satisfaction evaluations are weaker, or customers have less confidence in their evaluations, price may have more direct effects on loyalty" (Johnson et al., 2001, p. 233). Thus, in practical terms, Mittal, Ross and Baldasare (1998) perceived the importance of price and stated that customers are paying attention to price regarding their repurchase (loyalty) evaluations. In that paper, price is compared in terms of quality, other competitors (companies) and consumer expectations. Thus, it was expected that price could lead to loyalty.

\section{$\mathrm{H}_{3}$ : Price has a positive influence on customer's categorization of different loyalty groups}

The next construct is satisfaction. According to Zeithaml, Berry and Parasuraman (1996), customers who are more loyal are more likely to buy more. Loyalty reflects the degree to which customers' purchase and consumption experiences directly affect behavioral intention (Anderson, Fornell, \& Lehmann 1994; Johnson et al., 2001). For Andreassen and Lindestad (1997), who treated customer satisfaction as the accumulated experience of a customer's purchase and consumption experiences, this theoretical relation was empirically supported. Other studies also supported the relation between satisfaction and loyalty (Anderson \& Sullivan, 1993; Anderson \& Mittal, 2000; Gronholdt, Martensen, \& Kristensen, 2000; Gustafsson \& Johnson, 2002; Rust, Zahorik, \& Keiningham, 1995). In fact, the literature suggests that satisfaction positively influences customer buying intentions as well as their actual behavior (Bloemer \& Lemmick, 1992) and that there is a positive relationship between manifest satisfaction and store loyalty (Bloemer \& Ruyter, 1998). Thus, it is predictable that:

$\mathrm{H}_{4}$ : Satisfaction has a positive influence on the categorization of different loyalty groups. 
Concerning commitment, two relations are suggested in the loyalty model: the affective and calculative commitment relations.

In fact, relationship commitment relies on these dimensions that keep a customer loyal to a product or company, even when satisfaction and/or corporate image is low. According to Allen and Meyer (1990), moral store-commitment refers to a feeling of obligation towards an organization. Mathieu and Zajac (1990) claimed that moral commitment is rare in business relationships and, therefore, calculative commitment and affective commitment seem to be truly relevant to business relationships. Calculative commitment is the extent to which a person feels the need to maintain a relationship based on a cold, rational estimate of benefits in relation to switching costs (Hemetsberger \& Thelen, 2003). Calculative commitment has to do almost exclusively with non-psychological exit barriers (Hemetsberger \& Thelen, 2003). In contrast, affective commitment is defined as the desire to continue a relationship and expresses a sense of loyalty and belongingness (Morgan \& Hunt, 1994). Affective commitment is the emotional state which develops through the reciprocity between consumers and company (Gustafsson, Johnson, \& Ross, 2005).

According to Johnson et al. (2001), the affective commitment is hotter or conveys a more emotional evaluation since it captures the affective strength of the relationship that customers have towards a brand or company, and the level of involvement and trust that results. The calculative commitment serves as a psychological barrier to switching, since the calculative component is based on colder or more rational and economical aspects of the service. The relation (satisfaction $\rightarrow$ commitment $\rightarrow$ loyalty) has been studied and confirmed in a number of studies (Dick \& Basu, 1994; Prado \& Santos 2004; Pritchard, Havitz, \& Howard 1999; Santos 2001; Zins, 2001). However, these authors did not develop their studies in terms of affective and calculative commitment (first order construct). Therefore, based on the evidence given above, we have hypothesized that:

$\mathrm{H}_{5}$ : Affective Commitment has a positive influence on the categorization of different loyalty groups.

$\mathrm{H}_{6}$ : Calculative Commitment has a positive influence on the categorization of different loyalty groups.

Parasuraman and Grewal (2000) stated that the literature shows that value is a predictor of loyalty. Some studies have empirically observed that relation (Agustín \& Singh, 2002; Espartel, Rossi, \& Mulher, 2004; Johnson et al., 2001; Sirdeshmukh, Singh, \& Sabol, 2002). In practice, Santos (2001) showed that the concept of relational value presented a consistent explanation of loyalty because when consumers realize their money has an increased value in the relationship (cost vs. benefits), they present a tendency to continue buying. However, according to Parasuraman and Grewal (2000), "a lot of research has been focused on perceived value from the product perspective and not from the service perspective" (p. 169). From the service perspective, we assume that the greater the value (evaluation of the price paid by quality); the more loyal consumers will be. Therefore:

$\mathrm{H}_{7}$ : Value has a positive influence on the categorization of different loyalty groups

\section{RESEARCH DESIGN AND METHOD}

The service industry was used in this study. It was selected because such contexts enable consumers to observe and evaluate the behavior of service providers and are consistent with the behavioral focus of the loyalty construct. The total sample contained 264 people, who evaluated the supermarket system. A questionnaire was posted on the internet and sent to an e-mailing list (the same procedure used by Freire \& Nique, 2005). The universe of the research is people who purchased products at the supermarket. Therefore, the sample was characterized as non-probabilistic by convenience; furthermore, it was a snowball sample (Malhotra, 1996). A list of MBA executive students and a list of doctoral/master students was initially used. 
The measures were translated to Portuguese using the back-translation procedure (Malhotra, 1996). The next step was to pre-test the questionnaire with 22 people in order to verify the understanding and the meaning of the questions. Some questions were modified and a final version was developed. The measures were based on the Likert type scale and all items were taken from Johnson et al. (2001). These were 10-point scales, varying from low/high; from probably/improbably and from good/bad.

Conceptual Definitions. Customer Satisfaction is the consumer's response to the evaluations of the perceived discrepancy between prior expectations and the actual performance of the product as perceived after its consumption (Tse \& Wilton, 1988). Price is defined by the comparison of price to other indicators, such as quality, expectations etc. Corporate Image has been defined as perceptions of an organization reflected in the associations held in consumers' memory (Keller, 1993). Affective Commitment is the emotional state, which is developed through the reciprocity between consumers and company (Gustafsson et al. 2005). Complaint Handling is the action taken by an individual which involves communicating something negative regarding a product or service to either the firm manufacturing or marketing that product or service, or to some third-party organizational entity (Jacoby \& Jaccard, 1981, p. 6). Calculative Commitment is the extent to which a person feels a need to maintain a relationship based on a 'cold', rational estimate of benefits in relation to switching costs (Hemetsberger \& Thelen, 2003). Perceived Value is the consumer's overall assessment of the utility of a product based on perceptions of what is received and what is given (Zeithaml, 1988). Loyalty $_{\text {yes }}$ is a deeply held commitment to rebuy or repatronize a preferred product/service consistently in the future, thereby causing repetitive same-brand or same brand-set purchasing (Oliver, 1999).

Operational Definitions. Customer satisfaction contained 3 items, listed as: Overall satisfaction; Performance versus customer ideal service provider in the category and Expectation disconfirmation. Price included 3 items, listed as Price compared to quality; to other Companies and to Expectations. Corporate Image contained 4 items (Corporate image compared to other companies; Image of the store (branch) you deal with; what friends say about the corporate image and overall corporate image). Complaint Behavior had 2 items (The compensations offered by the company and whether employees treated you politely and with respect when you complained). Affective commitment contained 4 items (The pleasure taken from being a customer of the company; Identification with what the company stands for; Presence of reciprocity in the relationship and Feeling of belongingness to the company). Calculative commitment had 3 items (The economic benefits versus costs; Economic distress if the relationship is broken and Location advantages if compared to other companies). Value contained 2 items (evaluation of the price paid by quality and assessment of the quality by price paid). Loyalty was measured through a 10-point scale, varying from non-loyal to loyal, and contained 3 items (Likelihood of retention, Likelihood of speaking favorably about the company to others and Likelihood of recommending the company to others). Thus it was recoded in groups of $N o_{\text {loyalty }}$ and Yes loyalty.

\section{RESULTS}

For the hypothesis test, discriminant analysis was used. Thus, for this purpose, the data were preanalyzed according to some criteria. These criteria are described below. The missing values found were all below 10\% and they were replaced with means (Hair, Anderson, Tatham, \& Black ,1998). The variable that presented the maximum missing value percentage was $1.9 \%$. Outliers were verified according to two criteria: one is based on $Z$ score, where values above \pm 3 were deleted ( 5 cases), and the second one was based on Mahalanobis distance $\mathrm{D}^{2}$, where values under $p<0.001$ were deleted (no case was found). Therefore, the sample was reduced to 259 analyses. Since Loyalty was measured through a 10-point scale, it was recoded into two groups, $N o_{\text {loyalty }}$ and Yes loyalty. The points 4 to 7 of the 1 to 10 scale were excluded, in order to find a clearer division of the groups. The final categorization, after that division, was 105 analyses $\left(31 \% N_{\text {loyalty }}\right.$ and $68 \%$ Yes loyalty $)$.

Normality was checked in terms of kurtosis (values \pm 10 ), skweness $( \pm 3)$, and the Kolmogorov Smirnoff test (Kline, 1998). In these three features, all variables did not present any problems and they 
were all in compliance with the appropriate levels suggested by literature. Multicolinearity was assessed using Pearson correlations, where values above $r \pm 0.90$ were excluded because they could express the same variable. It was assessed in two stages: one in item-to-item and the other in construct-to-construct. Based on multicolinearity, one variable of loyalty was excluded $(r=0.93 ; p<$ 0.01 ; correlation with "loyalty_1") and another one of calculative commitment was excluded ( $r=0.97$; $p<0.01$; correlation with "image_2"). Thus, following these initial data check procedures, the multivariate analysis was used.

In the multivariate analysis stage, exploratory factor analysis (EFA) was used to verify the unidimensionality of the constructs (Dunn, Seaker, \& Waller, 1994). The purpose of using EFA was not only to define better variables that compose the factor (in terms of loads), but also to assess whether the constructs are unidimensional or multidimensional. Therefore, the criterion for excluding the variables in the matrix was loading $\lambda<0.40$. For extraction, the principal component analysis was used and for rotation the varimax method was employed (eigenvalues $>1$ ). Table 1 shows the results of that analysis.

According to the data, calculative commitment was the only construct which had an $\alpha$ under 0.70 (Bagozzi, Yi, \& Philips, 1991; Hair et al., 1998). As a comparative, this construct also presented a poor performance in the Johnson et al. (2001) study. In fact, calculative commitment had few values above the limit of $50 \%$ on average communality. This could be due to few items in the construct. In addition, price, which had 3 indicators in the questionnaire, was verified as multidimensional. For the purpose of analysis, this paper only used the first dimension of price.

Table 1: Unidimensionality Verification using Exploratory Factor Analysis

\begin{tabular}{lcccccc}
\hline Construct & Items before EFA & $\begin{array}{c}\text { Dimensions after } \\
\text { EFA }\end{array}$ & KMO & $\begin{array}{c}\text { Bartlett } \\
(p<0,01)\end{array}$ & Alpha $(\alpha)$ & VE\% \\
\hline Image & 4 & 1 & 0.85 & .000 & 0.91 & $78 \%$ \\
Affective commitment & 4 & 1 & 0.80 & .000 & 0.86 & $70 \%$ \\
Complaint & 2 & 1 & 0.50 & .000 & 0.70 & $77 \%$ \\
Satisfaction & 3 & 1 & 0.70 & .000 & 0.84 & $76 \%$ \\
$\quad$ Value & 2 & 1 & 0.50 & .000 & 0.94 & $94 \%$ \\
Calculative & 2 & 1 & 0.50 & .000 & $\mathbf{0 . 4 2}$ & $63 \%$ \\
Commitment & & & & & & \\
\hline$\quad$ Price & 3 & 2 & 0.48 & .000 & 0.84 & $57 \% * *$ \\
\hline Source: Authors; KMO=Kaiser Test; VE=Variance Extracted; ** The first dimension VE, adding the second dimension $=$ \\
91\%.
\end{tabular}

An analysis of the correlation matrix indicated some interesting results, as seen in Table 2. First, all variables in the model were significantly and positively related to the others $(p<0.01)$. Second, the major relation was between value and price $(r=.88, p<0.01)$. Third, the lowest relation was between image and calculative commitment $(r=.45, p<0.01)$. Mean and standard deviation (s.d.) are also presented in Table 2. 
Table 2: Correlation Matrix of the Constructs

\begin{tabular}{|c|c|c|c|c|c|c|c|c|c|c|}
\hline Measure & Mean & s.d. & Comp. & Sat. & Price & Val. & Calc. & Loy. & Ima. & Affe. \\
\hline Complaint & 7.48 & 1.70 & 1.00 & & & & & & & \\
\hline Satisfac. & 7.04 & 1.60 & 0.77 & 1.00 & & & & & & \\
\hline Price & 6.65 & 1.79 & 0.68 & 0.75 & 1.00 & & & & & \\
\hline Value & 6.96 & 1.73 & 0.69 & 0.78 & 0.88 & 1.00 & & & & \\
\hline $\begin{array}{l}\text { Calculative } \\
\text { Commitment }\end{array}$ & 7.22 & 1.70 & 0.53 & 0.60 & 0.60 & 0.56 & 1.00 & & & \\
\hline Loyalty & - & - & 0.71 & 0.78 & 0.67 & 0.70 & 0.49 & 1.00 & & \\
\hline Image & 7.51 & 1.56 & 0.53 & 0.77 & 0.60 & 0.70 & 0.45 & 0.64 & 1.00 & \\
\hline $\begin{array}{c}\text { Affective } \\
\text { commitment }\end{array}$ & 6.58 & 1.74 & 0.77 & 0.82 & 0.69 & 0.68 & 0.54 & 0.78 & 0.65 & 1.00 \\
\hline
\end{tabular}

The next table presents the result of the discriminant analysis (see Table 3) and hypothesis test. The canonical correlation, $\mathrm{R}_{C}$, is a measure of the association between the groups formed by the dependent variable and by the given discriminant function. Thus, when $\mathrm{R}_{\mathrm{C}}$ is zero, there is no relation between the groups and the function; when the canonical correlation is comprehensive, there is a high correlation between the discriminant functions and the groups (Garson, 2006). According to Hair et al. (1998) $R_{C}$ is used to find out how useful each function is in determining group differences and a $R_{C}$ of 1.0 indicates that all of the variability in the discriminant scores can be accounted for by that dimension. In that sense, the canonical correlation of the study was 0.884 . The squared value $\left(0.884^{2}=\right.$ 0.781 ) shows that $78 \%$ of the variance in the dependent variable is explained by the model (Hair et al., 1998) proposed by the paper. Thus, this research presents a satisfactory value for canonical correlation.

Table 3: Eigenvalues

\begin{tabular}{lcrrr}
\hline Function & Eigenvalue & $\%$ of Variance & Cumulative \% & $\begin{array}{c}\text { Canonical } \\
\text { Correlation }\end{array}$ \\
\hline 1 & $3.584^{\mathrm{a}}$ & 100.0 & 100.0 & .884 \\
\hline \multicolumn{4}{c}{ a. First 1 canonical discriminant functions were used in the analysis. }
\end{tabular}

As a consequence, it is important to test the null hypothesis in order to analyze whether the difference in the two groups is equal. According to Table 4, the Wilk's Lambda is the product of the univariate $\lambda$ of each function. The significant level was $p<0.001$, indicating that there is a significant difference in the evaluation of the two groups $\left(N_{\text {loyalty }}\right.$ and $\left.Y_{\text {es loyalty }}\right)$, rejecting the null hypothesis.

Table 4: Wilks' Lambda

\begin{tabular}{lrrrr}
\hline Test of Function(s) & Wilks' Lambda & Chi-square & df & \multicolumn{1}{c}{ Sig. } \\
\hline 1 & .218 & 154.536 & 3 & .000 \\
\hline
\end{tabular}


Table 5 presents the main goal of this paper, namely to identify the variables that distinguish the loyalty groups. According to the results, all constructs present a significant difference concerning the categorization of the groups. Note that satisfaction and affective commitment had the strongest $F$ values (above 200.00). In addition, the smaller the $\lambda$ (Wilks' Lambda) for an independent variable, the more that variable contributes to the discriminant function (Garson, 2006). The interpretation is that Lambda varies from 0 to 1 , where in 0 the groups' means differ (thus the more the variable differentiates the groups), and in 1 all the groups' means are the same.

Table 5: Tests of Equality of Group Means

\begin{tabular}{lccccc}
\hline & $\begin{array}{c}\text { Wilks' } \\
\text { Lambda }\end{array}$ & $\mathrm{F}$ & $\mathrm{df1}$ & $\mathrm{df2}$ & \multicolumn{1}{c}{ Sig. } \\
\hline IMAGE & .421 & 141.533 & 1 & 103 & .000 \\
AFFECTIVE COMP. & .272 & 275.167 & 1 & 103 & .000 \\
COMPLAINT & .366 & 178.137 & 1 & 103 & .000 \\
SATISFACTION & .267 & 283.282 & 1 & 103 & .000 \\
PRICE & .402 & 153.303 & 1 & 103 & .000 \\
VALUE & .367 & 177.622 & 1 & 103 & .000 \\
CALCULATIVE COMP. .701 & 44.012 & 1 & 103 & .000 \\
\hline
\end{tabular}

The discriminant method chosen was the stepwise method. For Garson (2006), the stepwise procedure selects the most correlated independent variables first, removes the variance in the dependent variables, then selects the second independent variable which most correlates with the remaining variance in the dependent variables, and so on until selection of an additional independent variable does not increase the canonical $\mathrm{R}$-squared by a significant amount (usually significant $=$ $0.05)$.

Consequently, the results showed that the three variables that were included in the model helped to improve the model $\mathrm{R}_{\mathrm{c}}{ }^{2}$ (see Table 6). They are affective commitment, satisfaction, and value. Table 6 presents the relative importance of independent variables. Hair et al. (1998) stated that the structural matrix (see Table 7) is considerably "accurate in identifying the variables that most help in differentiating groups" (p. 386).

Table 6: Standardized Canonical Discriminant Function Coefficients

\begin{tabular}{lc}
\hline & Function \\
\cline { 2 - 3 } & 1 \\
\hline AFFECTIVE COMP. & .547 \\
SATISFACTION & .369 \\
VALUE & .294 \\
\hline
\end{tabular}


Table 7: Structure Matrix

\begin{tabular}{lc}
\hline & Function \\
\cline { 2 - 2 } & 1 \\
\hline SATISFACTION & .876 \\
AFFECTIVE COMP. & .863 \\
VALUE & .694 \\
PRICE $^{\mathrm{a}}$ & .682 \\
COMPLAINT $^{\mathrm{a}}$ & .623 \\
IMAGE $^{\mathrm{a}}$ & .534 \\
CALCULATIVE $^{\mathrm{a}}$ & .495 \\
\hline
\end{tabular}

Pooled within-groups correlations between discriminating variables and standardized canonical discriminant functions Variables ordered by absolute size of correlation within function.

a. This variable was not used in the analysis.

Table 8 presents the centroid values (mean score for $Z$ ). This study hopes that the positive value for loyalty groups will be in the positive segment (i.e. Yes loyalty), discriminating from the $N o_{\text {loyalty }}$ groups. Therefore, the group centroid values confirmed this supposition presenting a $N o_{\text {loyalty }}=-2.770$.

Table 8: Functions at Group Centroids

\begin{tabular}{lc}
\hline & Function \\
\cline { 2 - 2 } Loyalty Groups & 1 \\
\hline No & -2.770 \\
Yes & 1.269 \\
\hline
\end{tabular}

Unstandardized canonical discriminant functions evaluated at group means

Categorization tables are the $2 \times 2$ tables in the discriminant analysis output for dependent variables, which tally correct and incorrect estimates. Discriminant function analysis is used to categorize cases into the values of a categorical dependent, usually a dichotomy; therefore, if the discriminant function analysis is effective for a set of data, the classification table of correct and incorrect estimates will yield a high percentage correct (Garson, 2006). In a perfect model, all cases will be on the diagonal and the overall percent for the correct estimate will be $100 \%$, which is very hard to find. The model presented in Table 9 shows an excellent percentage of $96.2 \%$ of correct overall categorization. 
Table 9: Categorization Results

\begin{tabular}{lllrrr}
\hline & & \multicolumn{2}{c}{ Predicted Group Membership } & \\
\cline { 3 - 5 } & & Loyalty Groups & No & Yes & Total \\
\hline Original & Count & No & 32 & 1 & 33 \\
& & Yes & 3 & 69 & 72 \\
& & Ungrouped cases & 45 & 109 & 154 \\
\cline { 2 - 5 } & No & 97.0 & 3.0 & 100.0 \\
& Yes & 4.2 & 95.8 & 100.0 \\
& Ungrouped cases & 29.2 & 70.8 & 100.0 \\
\hline
\end{tabular}

a. $96.2 \%$ of original grouped cases correctly ranked.

\section{HYPOTHESIS DISCUSSION}

The first hypothesis was supported in this research. This means that corporate image has a positive influence on the categorization of loyalty groups. Andreassen and Lindestad $(1997,1998)$ found in their study that corporate image not only had a significant effect, but also a stronger effect on loyalty than customer satisfaction. In this paper, image has a significant impact on the differentiation of the loyalty groups, so that a better environment, a better look of the store etc. is associated with customer repurchase. The research carried out by Chebat and Michon (2003) showed that the store environment has an influence on sales (Milliman, 1986), product evaluation, and satisfaction (Bitner, 1990). From the analysis, it is important to state that after being included in the model, the variable image failed to improve the $\mathrm{R}_{\mathrm{c}}{ }^{2}$ of the model, although it had a positive and significant impact. In short, supermarket marketing professionals could consolidate loyalty groups by creating an enhanced buying experience (e.g. investment in color, smell, illumination) and a practical environment, e.g. striking pleasure and arousal (Donovan \& Rossiter, 1982; Underhill, 1999).

The second hypothesis that was supported stated that complaint handling has a significant impact on discriminating loyalty groups. In fact, complaint handling has been considered to be an important tool for managers to deal with failures, especially in the services sector, where customers evaluate a performance and not a tangible product (Grönroos, 1988; Stauss \& Seidel, 2004). Since most of the customers do not complain when they experience a service failure (Tax \& Brown, 1998), they simply choose another service provider and it becomes clear that monitoring customer satisfaction over time is not enough. In that sense, a well-handled complaint has a positive effect on satisfaction, which has an impact on consumer repurchase and future real intention (Gilly \& Gelb, 1982). It is important to mention that this causal result is not in agreement with the empirical finding presented by Johnson et al. (2001), and our result could mean that making a complaint might indicate that consumers know that (when they complain) the organization will treat the suggested idea as important, which could lead to a new purchase in the future.

The third relation stated that price has a positive influence on customer loyalty. This was supported ( $F 153.303$, d.f. $=1 ; p<0.000)$. Price is a well known variable in the retailing context, especially in supermarkets. In this research, price is conceptualized as the price paid compared to quality received, price paid compared to other competitor companies and price paid compared to established expectations. Therefore, it is evident that consumers think about the price of products and compare prices with those offered by competitors. Once individuals realize the price is lower than they expected and lower than that offered by the competitor, they tend to constantly repurchase products in 
the same store. Therefore, supermarkets have price as a strategic tool to create reference points and increase loyalty among customers.

The fourth hypothesis is a classical hypothesis. It assumes that customer satisfaction has a positive influence on consumer loyalty. According to the results, this relation is supported and the function was equal to $0.369(p<0.01)$. The result of this hypothesis follows the same results found by other studies (Anderson, et al. 1994; Anderson \& Sullivan 1993; Anderson \& Mittal, 2000; Bruhn 2003; Gronholdt et al. 2000; Gustafsson \& Johnson, 2002; Rust et al., 1995) and shows how important it is for the supermarket segment to invest in this construct. The explanation for this result is that from the point of view of the customer who repurchases at the same store, each specific transaction with a supplier serves as the basis for a satisfaction assessment. These specific assessments, in turn, are assumed to result in an accumulated level of satisfaction (Söerlund, 2002). The accumulated satisfaction level is adjusted in light of each additional transaction so that it represents a continuously updated account of customers' relationship with suppliers.

Hypothesis number five-to-six analyzes commitment. In this study, we define relationship commitment as the enduring desire of customers to continue a relationship with a seller, along with their willingness to make efforts to maintain it (Pritchard et al. 1999). Affective commitment (more emotional) and calculative commitment (more rational) supposedly influence customer loyalty. The first result regarding commitment is that the factor loads and alpha cronbach value for calculative commitment was low. Thus, since the alpha for calculative commitment $(\alpha=0.42)$ was below the value indicated by theory (Hair et al., 1998), it was decided not to test this hypothesis. Therefore, future research could generate more accurate items for measuring the calculative commitment in the supermarket context. The second result is that affective commitment was the major exogenous variable to discriminate the groups in the model (canonical function 0.547). In this context, the pleasure taken from being a customer of the company, the personal identification with what the company stands for, the presence of reciprocity in the relationship (i.e. fairness concept and Equity Theory), and the feeling of belongingness to the company are indicators of repurchase.

The seventh hypothesis assumes that value has a positive influence on the categorization of Loyalty groups. The results appear to be similar to other results found (Agustín \& Singh, 2002; Espartel et al. 2004; Johnson et al., 2001; Sirdeshmukh et al. 2002) and indicated a canonical function of 0.547 , indicating the last variable significantly improves the loyalty variance.

\section{CONCLUSIONS}

Regarding the intention of this study, i.e., to identify the variables that discriminate loyalty groups, it can be said that the (a) affective commitment towards the supermarket, (b) satisfaction with the supermarket service and its environment, and (c) value provided by the supermarket experience appear to be important constructs in the loyalty context, because some theoretical propositions were supported in this study.

An important consideration is that the antecedents of loyalty need to be further explored because, of the seven constructs that were allegedly antecedents, only three were supported in terms of significantly improving the variance in the dependent variable (i.e. $\mathrm{R}_{\mathrm{c}}{ }^{2}$ ), although all associations were supported. The affective commitment, i.e. the idea of emotional evaluation, since it captures the affective strength of the relationship that customers have with a brand or company, seems to be truly relevant and should be one of the priorities for marketing professionals. The concept of effectiveness comprehends the affinity and sympathy in the relationship between the buyer and the retailer. Programs such as bonuses, credit cards, and so forth, can help increase sales, since they properly establish the individual-organization. 
Another important result is that the outcomes indicated that the theoretical model achieved a loyalty construct variance of $\mathrm{R}_{\mathrm{c}}{ }^{2}=0.78$. This could be considered a good value (Hair et al., 1998) for the final model. For example, $96.2 \%$ of the original grouped cases were correctly categorized, which proved the accuracy of the model.

In short, the hypothesis suggested seems to be a valuable tool for understanding the dynamics of loyalty. Other studies might refine the propositions suggested here and further advance the understanding of loyalty, especially when it comes to the consequences, such as word of mouth marketing intentions. In this way, researchers that work with consumers' behavior should keep on studying purchase intentions at a deeper level (Oliver, 1999).

\section{LIMITATIONS AND DIRECTIONS FOR FUTURE RESEARCH}

This study has a few limitations that ought to be mentioned here. The first restriction of this study is its cross-sectional nature. Alternative longitudinal methodologies should be employed in future research. The second restriction concerns the sample used in the study. It is difficult to generalize the findings obtained here because this sample differs in several aspects from non-internet users. Additionally, non-student samples could be considered in future studies. For example, through a mailing list obtained from the Carrefour, BIG, and Wall Market supermarkets.

The product category used as stimulus (supermarket context) in this study presented some interesting features that accounted for its inclusion here. However, further studies should consider analyzing more product categories in the retail market, in order to validate the results found here (for example, drugstores, banks, private universities, gas-stations etc.). Finally, we hope the debate resulting from this paper may encourage other researchers to test the hypotheses in more favorable circumstances, without the limitations of our study in order to achieve a better understanding of the variables that could account for the main differences between loyalty groups.

\section{REFERENCES}

Agustín, C., \& Singh, J. (2002). Satisfaction, trust, value and consumer loyalty: curvilinearities in relationship dynamics. Proceedings of the Conference of European Marketing Academy, Braga, Portugal, 31 .

Allen, N. J., \& Meyer, J. P. (1990). The measurement and antecedents of affective, continuance, and normative commitment to the organization, Journal of Occupational Psychology, 63(1), 01-18.

Anderson, E. W., \& Mittal, V. (2000). Strengthening the satisfaction profit chain. Journal of Service Research, 3(2), 107-120.

Anderson, E. W., \& Sullivan M. (1993). The antecedents and consequences of customer satisfaction for firms. Marketing Science, 12(2), 125-143.

Anderson, E. W., Fornell, C., \& Lehmann, D. R. (1994). Customer satisfaction, market share, and profitability: findings from sweden. Journal of Marketing, 58(3), 53-66.

Andreassen, T. W., \& Lindestad, B. (1997). Customer loyalty and complex services: the impact of corporate image on quality, customer satisfaction and loyalty or customers with varying degrees of service expertise. International Journal of Service Industry Management, 8(4), 01-33. 
Andreassen, T. W., \& Lindestad, B. (1998). The Impact of Corporate Image in the Formation of Customer Loyalty. Journal of Service Research, 1(1), 82-92.

Assael, H. (1998). Consumer behavior \& marketing action (6th ed.). South-Western Pub.

Bagozzi, R. P., Yi, Y., \& Philips, L. W. (1991). Assessing construct validity in organizational research. Administrative Science Quarterly, 36(3), 421-458.

Bitner, M. J. (1990). Evaluating service encounters: the effects of physical surroundings and employee responses. Journal of Marketing, 54(2) 69-82.

Blodgett, J. G., Hill, D. J., \& Tax, S. S. (1997). The effects of distributive, procedural, and interactional justice on postcomplaint behavior. Journal of Retailing, 73(2), 185-210.

Bloemer, J., \& Lemmink, J. G. A. M. (1992). The importance of customer satisfaction in explaining brand and dealer loyalty. Journal of Marketing Management, 8(4), 351-364.

Bloemer, J., \& Ruyter, K. (1998). On the relationship between store image, store satisfaction and store loyalty. European Journal of Marketing, 32(5-6), 499-513.

Bloemer, J., \& Schroder, G. (2002). Store satisfaction and store loyalty explained by customer and store related factors. Journal of Consumer Satisfaction, Dissatisfaction and Complaint Behavior, 15, 86-80.

Bruhn, M. (2003). Internal service barometers: conceptualization and empirical results of a pilot study in Switzerland. European Journal of Marketing, 37(9), 1187-1204.

Chebat, J. C., \& Michon, R. (2003). Impact of ambient odors on mall shoppers' emotions, cognition and spending: a test of competitive causal theories. Journal of Business Research, 56(7) 529539.

Dick, A. S., \& Basu, K. (1994). Customer loyalty: toward an integrated conceptual framework. Journal of the Academy of Marketing Science, 22(2), 99-113.

Donovan, R. J., \& Rossiter, J. R. (1982). Store atmosphere: an environmental psychology approach. Journal of Retailing, 58(1), 34-57.

Dunn, S. C., Seaker, R. F., \& Waller, M. A. (1994). Latent variable in business logistics research: scale development and validation. Journal of Business Logistics, 15(2), 145-173.

Espartel, L. B., Rossi, C. A. V., \& Mülher, H. F. (2004). Teste de um modelo de antecedentes da lealdade em três situações de consumo distintas. Anais do Encontro de Marketing da ANPAD. Porto Alegre, RS, Brasil, 1.

Fornell C. (1992). A national customer satisfaction barometer: the swedish experience. Journal of Marketing, 6(1), 06-21.

Freire, K. M., \& Nique, W. M. (2005). A influência do envolvimento com o produto e do comprometimento com a marca na lealdade à marca. Anais do Encontro Nacional dos Programas de Pós-Graduação em Administração, Brasília, DF, Brasil, 29.

Garson, D. (2006). Discriminant analysis. Retrieved January 21, 2006, from http://www2.chass.ncsu.edu/garson/pa765/logistic.htm

Gilly, M. C., \& Gelb, B. (1982). Post-purchase consumer processes and the complaining consumer. Journal of Consumer Research, 9(3), 323-328.

Goodwin, C., \& Ross, I. (1992). Consumer responses to service failures: influence of procedural and interactional fairness perceptions. Journal of Business Research, 25(3), 149-163. 
Gronholdt, L., Martensen, A., \& Kristensen, K. (2000). The relationship between customer satisfaction and loyalty: cross-industry differences. Total Quality Management, 11(4-6), S509-S515.

Grönroos, C. (1988). Service quality: the six criteria of good perceived service quality. interactional justice on postcomplaint behavior. Journal of Retailing, 73(2), 185-210.

Gustafsson, A., \& Johnson, M. D. (2002). Measuring and managing the satisfaction-loyaltyperformance links at Volvo. Journal of Targeting, Measurement and Analysis for Marketing, $10(3), 249-258$.

Gustafsson, A., Johnson, M. D., \& Roos, I. (2005). The effects of customer satisfaction, relationship commitment dimensions, and triggers on customer retention. Journal of Marketing, 69(4), 210218.

Hair, J., Anderson, R. E., Tatham, R., \& Black, W. (1998). Multivariate data analysis. New Jersey: Prentice Hall.

Hemetsberger, A., \& Thelen, E. (2003). What characterizes truly loyal online shoppers? Modeling the influence of variety seeking, satisfaction, trust and involvement on online-store commitment. European Advances in Consumer Research, 6, 361-367.

Jacoby, J., \& Jaccard, J. J. (1981). The sources, meaning, and validity of consumer complaint behavior: a psychological analysis. Journal of Retailing, 57(3), 4-24.

Johnson, M. D., Gustafsson, A., Andreassen, T. W., Lervik, L., \& Cha, J. (2001). The evolution and future of national customer satisfaction index models. Journal of Economic Psychology, 22(2), 217-245.

Keller, K. (1993). Conceptualizing, measuring and managing customer based equity. Journal of Marketing, 57(1), 01-23.

Kline, R. B. (1998). Principles and practice of structural equation modeling. New York: Guilford Press.

Kristensen, K., Martensen, A., \& Gronholdt, L., (2000). Customer satisfaction measurement at post Denmark: results of application of the European customer satisfaction index methodology. Total Quality Management, 11(7), S1007-S1016.

Lee, E., \& Lee, D. (2005). The effect of internet service quality on internet store loyalty: mediating role of internet store satisfaction and internet store image. In Y. U. Ha \& Y. Youjae (Eds.). Asia Pacific advances in consumer research (Vol. 6, pp. 386-392). Duluth, MN: Association for Consumer Research.

Leite, R. S., Elias, C. L., \& Sundermann, J. (2005). O índice europeu de satisfação de clientes (ECSI): um estudo empírico de sua aplicação em uma empresa brasileira fornecedora de ERP. Anais do Encontro Nacional dos Programas de Pós-Graduação em Administração, Brasília, DF, Brasil, 29.

Loughlin. O. C., \& Coenders, G. (2002, September). Application of the european customer satisfaction index to postal services: structural equation models versus partial least squares [Working Paper], Universitat de Girona, Spain.

Malhotra, N. K. (1996). Marketing research: an applied orientation. Englewood Cliffs: Prentice Hall.

Mathieu, J. E., \& Zajac, D. M. (1990). A review and meta-analysis of the antecedents, correlates and consequences of organizational commitment. Psychological Bulletin, 108(2), 171-194. 
Messick, D., \& Cook, K. (1983). Equity theory: psychological and sociological perspectives. New York: Praeger.

Milliman, R. E. (1986). The influence of background music on the behavior of restaurant patrons. Journal of Consumer Research, 13(2), 286-289.

Mittal, V., Ross, W. T., \& Baldasare, P. M. (1998). The asymmetric impact of negative and positive attribute-level performance on overall satisfaction and repurchase intentions. Journal of Marketing, 62(1), 33-47.

Morgan, R. M., \& Hunt, S. D. (1994). The commitment-trust theory of relationship marketing. Journal of Marketing, 58(3), 20-38.

Oliver, R. L. (1997). Satisfaction: a behavioral perspective on the consumer. New York, McGrawHill.

Oliver, R. L. (1999). Whence the consumer loyalty. Journal of Marketing, 63(Special Edition), 33-44.

Parasuraman, A., \& Grewal, D. (2000). The impact of technology on the quality-value-loyalty chain: a research agenda. Journal of the Academy of Marketing Science, 28(1), 168-174.

Prado, P. H. M., \& Santos, R. C. (2004). Satisfação, qualidade no relacionamento e lealdade entre clientes e bancos de varejo. Anais do Encontro de Marketing da ANPAD, Porto Alegre, RS, Brasil, 1.

Pritchard, M. P., Havitz, M. E., \& Howard, D. R. (1999). Analyzing the commitment-loyalty link on service contexts. Journal of the Academy of Marketing Science, 27(3), 333-348.

Rust, R. T., Zahorik, A. J., \& Keiningham T. L. (1995). Return on quality (ROQ): making service quality financially accountable. Journal of Marketing, 59(2), 58-70.

Santos, C. P., \& Singh, J. (2003). Fairness in complaint handling: exploring a cross-cultural perspective. Anais do Encontro Nacional dos Programas de Pós-Graduação em Administração, Campinas, SP, Brasil, 27.

Santos, C. P. (2001). Impacto do gerenciamento de reclamações na confiança e lealdade do consumidor, no contexto de trocas relacionais de serviços: construção e teste de um modelo teórico. Tese de Doutorado, Universidade Federal do Rio Grande do Sul, Porto Alegre, Brasil.

Selnes, F. (1993). An examination of the effect of product performance on brand reputation, satisfaction and loyalty. European Journal of Marketing, 27(9), 19-35.

Sirdeshmukh, D., Singh, J., \& Sabol, B. (2002). Consumer trust, value, and loyalty in relational exchanges. Journal of Marketing, 66(1), 15-37.

Sirohi, N., McLaughlin, E. W., \& Wittink, D. R. (1998). A model of consumer perceptions and store loyalty intentions for a supermarket retailer. Journal of Retailing, 74(2), 223-245.

Söerlund, M. (2002). Customer satisfaction as a gain/loss situation: are experienced customers more loss aversive? Proceedings of the Conference of European Marketing Academy, Braga, Portugal, 31 .

Stauss, B., \& Seidel, W. (2004). Complaint management: the heart of CRM. Ohio: Thompson Publishing USA.

Ster, B., Zinkhan, G. M., \& Jaju, A. (2001). Marketing Images: construct definition, measurement issues, and theory development. Marketing Theory, 1(2), 201-224.

Stauss, B., \& Seidel, W. (2004). Complaint Management: the heart of CRM. Cincinnati: Thompson. 
Tax, S. S., \& Brown, S. (1998). Recovering and learning from service failure. Sloan Management Review, 40(1), 75-88.

Tax, S. S., Brown, S. W., \& Chandrashekaran, M. (1998). Customer evaluations of service complaint experiences: implications for relationship marketing. Journal of Marketing, 62(2), 60-76.

Thibaut, J., \& Kelley, H. H. (1959). The social psychology of groups. New York: Wiley.

Tse, D. K., \& Wilton, P. C. (1988). Models of consumer satisfaction formation an extension. Journal of Marketing Research, 25(2), 204-212.

Underhill, P. (1999). Vamos as compras: a ciência do consume. Rio de Janeiro: Campus.

Zeithaml, V. A. (1988). Consumer perceptions of price, quality, and value: a means-end model and synthesis of evidence. Journal of Marketing, 52(3), 2-22.

Zeithaml, V. A., Berry, L., \& Parasuraman, A. (1996). The behavioral consequences of service quality. Journal of Marketing, 60(2), 31-47.

Zins, A. H. (2001). Relative attitudes and commitment in customer loyalty models. International Journal of Service Industry Management, 12(3-4), 269-294. 